\title{
Analisis Promosi Jabatan Terhadap Produktivitas dan Semangat Kerja Pegawai Negeri Sipil Sekretariat Pemerintah Kota Makassar
}

\author{
${ }^{1}$ Hafiz Elfiansya Parawu, ${ }^{2}$ Nurliah Binti Rahmat, ${ }^{3}$ Mappamiring \\ Universitas Muhammadiyah Makassar, Makassar, Indonesia \\ Email:1hafiz@unismuh.ac.id
}

(Diterima: November 2021; Direvisi: Desember 2021; Dipublikasikan: Januari 2022)

\begin{abstract}
ABSTRAK
Promosi jabatan diyakini dapat berpengaruh pada produktivitas dan semangat kerja pegawai. Penelitian ini bertujuan untuk menganalisis pengaruh promosi jabatan terhadap produktivitas dan semangat kerja pegawai negeri sipil (PNS) Sekretariat Pemerintah Kota Makassar. Penelitian ini berjenis penelitian kuantitatif dengan populasi sekaligus sampel penelitian sebanyak 45 orang PNS Sekretariat Pemerintah Kota Makassar. Teknik pengumpulan data menggunakan kuesioner dan menggunakan teknik analisis regresi linier sederhana, dengan pengabsahan data melalui uji validitas, reliabilitas, normalitas, dan linieritas data. Hasil penelitian menunjukkan bahwa promosi jabatan memengaruhi produktivitas dan semangat kerja PNS Sekretariat Pemerintah Kota Makassar yang telah mendapatkan promosi jabatan pada tahun 2020 .
\end{abstract}

Kata Kunci: Promosi Jabatan, Produktivitas Kerja, Semangat Kerja 


\section{PENDAHULUAN}

Pegawai Negeri Sipil (PNS) sebagai sumber daya manusia yang berada di sektor pemerintahan berperan penting atas keberhasilan dalam pelaksanaan penyelenggaraan pemerintahan dan pembangunan nasional. Kedudukan dan peranannya juga sangat penting dalam menghadapi arus globalisasi dan sebagai pelaksana dari usaha kegiatan pemerintah. PNS berkedudukan sebagai unsur aparatur negara yang bertugas untuk memberikan pelayanan kepada masyarakat secara profesional, jujur, adil, dan merata dalam penyelenggaraan tugas negara, pemerintahan, dan pembangunan (Undang-Undang Nomor 5 Tahun 2014 tentang Aparatur Sipil Negara).

Manajemen Aparatur Sipil Negara lebih menekankan kepada pengaturan profesi pegawai, sehingga diharapkan agar selalu tersedia sumber daya aparatur sipil negara yang unggul selaras dengan perkembangan jaman, sehingga diperlukan adanya peningkatan produktivitas kerja. Dimana produktivitas kerja dapat diartikan sebagai cara kerja atau metode kerja pegawai dalam melaksanakan tugas pekerjaannya, yang dapat dilihat melalui kesediaan para pegawai untuk bekerja secara efektif dan efisien (Kusnendi, 2003).

Guna memertahankan dan meningkatkan produktivitas kerja pegawai, maka instansi wajib memerhatikan kebutuhan pegawai, baik yang bersifat materi maupun non materi, sebagai wujud perhatian dan dorongan yang dilakukan oleh instansi terhadap pegawai. Salah satunya adalah melaksanakan promosi jabatan yang objektif dan adil serta penempatan yang tepat.

Menurut Siagian (2009), promosi jabatan adalah pemindahan pegawai atau karyawan dari satu jabatan atau tempat kepada jabatan atau tempat yang lebih tinggi serta diikuti oleh tugas, tanggung jawab, dan wewenang yang lebih tinggi dari jabatan yang di duduki sebelumnya dan pada umumnya promosi yang diikuti dengan peningkatan income serta fasilitas yang lain.

Promosi jabatan yang objektif dan adil diyakini dapat memengaruhi produktivitas kerja pegawai, seperti penelitian yang dilakukan oleh Aisah (2018), pada karyawan Hotel Harris Vertu Yello Harmoni Jakarta, dimana hasil penelitiannya menunjukkan bahwa variabel promosi jabatan berpengaruh terhadap variabel produktivitas kerja karyawan. Begitu pula dengan penelitian Rismayanti dkk (2019), pada karyawan PT. Star Comgistic Indonesia Kabupaten Sukabumi, dimana hasil penelitiannya menunjukkan bahwa terdapat pengaruh positif dan signifikan antara promosi jabatan terhadap produktivitas kerja karyawan. Namun, tidak selamanya pula promosi jabatan berpengaruh terhadap produktivitas kerja. Penelitian yang dilakukan oleh Pramitasari (2018), pada karyawan PT. Pos Indonesia (PERSERO) Kabupaten Situbundo, ternyata menunjukkan bahwa promosi jabatan tidak berpengaruh nyata terhadap produktivitas kerja karyawan.

Promosi jabatan juga sangat memengaruhi semangat kerja pegawai dalam suatu instansi dan memberikan dampak yang postif terhadap kinerja pegawai. Ada 
beberapa sebab perlunya diambil tindakan promosi, diantaranya ialah memertinggi semangat kerja pegawai, bilamana menghasilkan prestasi kerja yang tinggi maka ada daya perangsang bagi para pegawai untuk memertinggi semangat kerjanya (Manulang, 2001).

Siswanto

(2003), mendefinisikan semangat kerja sebagai keadaan psikologis seseorang. Semangat kerja dianggap sebagai psikologis yang baik bila semangat kerja tersebut tersebut menimbulkan kesenangan yang mendorong seseorang untuk bekerja dengan giat dan konsekuen dalam mencapai tujuan yang ditetapkan oleh perusahaan. Ada banyak cara dilakukan agar pegawai dapat bekerja dengan semangat yang tinggi antara lain dengan pemenuhan kebutuhan materi, misalnya gaji atau upah, bonus atau tunjangan lainnya, maupun pemenuhan kebutuhan non materi, seperti penghargaan dan pujian dari atasan, suasana kerja yang menyenangkan dan adanya pelaksanaan promosi jabatan.

Promosi jabatan yang objektif dan adil juga diyakini dapat memengaruhi semangat kerja pegawai, seperti penelitian yang dilakukan Ramadhanni (2015), pada karyawan divisi redaksi pada PT. Tribun Pekanbaru, dimana menunjukkan bahwa promosi jabatan berpengaruh signifikan terhadap semangat kerja karyawan. Begitu pula dengan penelitian yang dilakukan oleh Setiawan (2018), pada pegawai di Lingkungan Universitas Pembangunan Pancabudi Medan, dimana hasil penelitiannya menunjukkan bahwa ada pengaruh promosi jabatan terhadap semangat kerja pegawai.

Sekretariat Pemerintah Kota Makassar merupakan lembaga pemerintah yang berwenang mengatur dan mengurus urusanurusan pemerintahan yang berkedudukan sebagai Lembaga Pemerintahan Kota. Hal terpenting yang perlu diperhatikan berkaitan dengan pembinaan aparatur sipil negara, baik pembinaan sikap mental, karir, maupun jabatan merupakan hal mutlak yang harus dilakukan agar memeroleh sumber daya manusia yang handal, tangguh, disiplin, bermoral serta mampu memiliki etos kerja yang tinggi sebagai abdi negara dan abdi masyarakat yang memiliki keteladanan dan mengabdi pada pelayanan masyarakat. Maka pihak instansi perlu memberi perhatian kepada aparatur, khususnya PNS yang berprestasi, dengan memberikan penghargaan dalam bentuk promosi atau kenaikan jabatan yang berdampak positif dalam meningkatkan produktivitas dan semangat kerja PNS Sekretariat Pemerintah Kota Makassar.

Hasil observasi awal peneliti (14/04/2021), setelah mewawancarai 7 orang PNS Sekretariat Pemerintah Kota Makassar yang telah mendapatkan promosi jabatan pada tahun 2020, menemukan bahwa: (1) Proses promosi jabatan belum berjalan secara adil dan objektif; (2) Penempatan pegawai di jabatan yang baru masih ada yang belum begitu sesuai dengan latar belakang pendidikannya; dan (3) Penempatan pegawai di jabatan yang baru tidak berkesesuaian dengan pengalaman kerjanya selama ini. 
Berbagai permasalahan terkait promosi jabatan ini tentu saja dapat berdampak pada produktivitas dan semangat kerja PNS Sekretariat Pemerintah Kota Makassar yang telah mendapatkan promosi jabatan pada tahun 2020. Maka, tujuan penelitian ini berdasarkan latar belakang permasalahan yang telah dikemukakan adalah guna menganalisis pengaruh promosi jabatan terhadap produktivitas dan semangat kerja PNS Sekretariat Pemerintah Kota Makassar yang telah mendapatkan promosi jabatan pada tahun 2020.

\section{TINJAUAN PUSTAKA}

\section{Promosi Jabatan}

Nawawi (2011), mengemukakan bahwa promosi jabatan adalah apabila seorang pegawai dipindahkan dari satu pekerjaan ke pekerjaan yang lain yang tanggung jawabnya lebih besar, tingkatannya dalam hierarki jabatan lebih tinggi, dan penghasilannya juga lebih besar. Promosi jabatan menurut Hasibuan (2016), adalah perpindahan yang memerbesar wewenang dan tanggung jawab ke jabatan yang lebih tinggi di dalam suatu organisasi yang diikuti dengan kewajiban, hak, status, dan penghasilan yang lebih besar pula. Maka, promosi jabatan pada hakekatnya adalah kenaikan tingkat jabatan seorang pegawai ke suatu tingkat jabatan yang lebih tinggi dari sebelumnya dan diikuti oleh tugas, wewenang, dan tanggung jawab yang lebih besar, serta kenaikan penghasilan.

Dalam melakukan promosi jabatan, memiliki syarat-syarat tertentu (Siagian, 2009), yaitu: (1) Pengalaman; (2) Tingkat pendidikan; (3) Loyalitas; (4) Kejujuran; (5) Tanggung jawab; (6) Kepandaian bergaul; (7) Prestasi kerja; dan (8) Inisiatif dan kreatif.

\section{Produktivitas Kerja}

Produktivitas mengandung arti sebagai perbandingan antara hasil yang dicapai (output) dengan keseluruhan sumber daya yang digunakan (input). Dengan kata lain, produktivitas memiliki 2 (dua) dimensi, yaitu dimensi efektivitas yang mengarah kepada pencapaian untuk kerja yang maksimal, baik dari segi kualitas, kuantitas, dan waktu. Sedangkan, dimensi efesiensi berkaitan dengan upaya membandingkan input dengan realisasi penggunaannya atau bagaimana pekerjaan tersebut dilaksanakan (Ashari, 2009).

Produktivitas menurut Dewan Produktivitas Nasional adalah sikap mental yang selalu berpandangan bahwa mutu kehidupan hari ini harus lebih baik dari hari kemarin dan esok hari harus lebih baik dari hari ini (Umar, 2000). Adapun menurut Mathis (2012), produktivitas kerja merupakan pengukuran dan kuantitas dari pekerjaan dengan memertimbangkan seluruh biaya dan hal yang terkait, serta yang diperlukan dalam pekerjaan tersebut. Maka, dapat disimpulkan bahwa produktivitas kerja adalah unsur yang penting dalam sebuah organisasi untuk dapat melaksankan tugas kerjanya secara efektif dan efesien dalam rangka pencapaian tujuan. 
Anoraga

(2004), mengemukakan faktor-faktor yang dapat memengaruhi produktivitas kerja pegawai atau karyawan, yaitu: (1) Motivasi;

Pendidikan; (3) Keterampilan; (4) Sikap etika kerja; (5) Tingkat penghasilan; dan (6) Teknologi

\section{Semangat Kerja}

Tohardi mendefinisikan semangat kerja adalah kemampuan sekelompok orang-orang yang bekerja sama dengan giat dan konsekuen dalam mengejar tujuan bersama. Adapun Siswanto (2003), mengartikan semangat kerja sebagai kesenangan tenaga kerja untuk melaksankan suatu pekerjaan yang diserahkan kepadanya sehingga pekerjaan tersebut dapat diselesaikan tepat waktu.

Sedangkan Rival, dkk (2005), mendefinisikan semangat kerja sebagai setiap kesediaan perasaan yang memungkinkan seseorang bekerja untuk menghasilkan kerja lebih banyak dan lebih baik. Maka, dapat disimpulkan bahwa semangat kerja adalah suatu keinginan atau kesungguhan yang timbul pada diri seseorang atau kelompok yang bekerja sama sehingga pekerjaan tersebut dapat selesai pada tepat waktu agar tujuan yang diinginkan dapat tercapai. Dan menurut Handoko (1996), ada 2 (dua) faktor yang memengaruhi semangat kerja, yaitu: Komunikasi; dan (2) Motivasi.

Adapun hipotesis dalam penelitian ini, adalah:

H1 :Promosi jabatan berpengaruh terhadap produktivitas kerja PNS Sekretariat Pemerintah Kota Makassar.

$\mathrm{H} 2$ :Promosi jabatan berpengaruh terhadap semangat kerja PNS Sekretariat Pemerintah Kota Makassar.

\section{METODE PENELITIAN}

Penelitian ini berjenis penelitian kuantitatif dengan menggunakan metode penelitian survey bertipe penelitian asosiatif. Populasi sekaligus sampel dalam penelitian ini sebanyak 45 orang PNS Sekretariat Pemerintah Kota Makassar yang telah mendapatkan promosi jabatan pada tahun 2020 . Teknik pengumpulan data yang digunakan adalah dengan menggunakan kuesioner (angket) dan studi dokumentasi. Teknik analisis data menggunakan teknik analisis regresi linier sederhana dengan pengabsahan data melalui uji validitas, reliabilitas, normalitas, dan linieritas data dengan menggunakan bantuan softwareSPSS version 20.0.

\section{HASIL PENELITIAN DAN PEMBAHASAN}

A. Hasil Uji Regresi Linier Sederhana Pengaruh Promosi Jabatan (X) terhadap Produktivitas Kerja (Y1)

Tabel 1.

Model Summary

\begin{tabular}{|c|c|c|c|c|}
\hline $\begin{array}{l}\text { Mode } \\
1\end{array}$ & $\mathrm{R}$ & R Square & $\begin{array}{c}\text { Adjusted R } \\
\text { Square }\end{array}$ & $\begin{array}{l}\text { Std. Error of } \\
\text { the Estimate }\end{array}$ \\
\hline 1 & $.806^{\mathrm{a}}$ & .649 & .641 & 1.20642 \\
\hline
\end{tabular}

a. Predictors: (Constant), Promosi Jabatan 
Tabel 1 menjelaskan besarnya nilai korelasi atau hubungan (R) yaitu sebesar 0,806. Adapun nilai koefisien determinasi ( $\mathrm{R}$ Square) sebesar 0,649, yang mengandung arti bahwa pengaruh promosi jabatan $(\mathrm{X})$ terhadap produktivitas kerja (Y1) adalah sebesar 64,9\%. Hasil ini juga

Tabel 2

ANOVA

\begin{tabular}{|c|c|c|c|c|c|}
\hline Model & $\begin{array}{c}\text { Sum of } \\
\text { Squares }\end{array}$ & Df & $\begin{array}{c}\text { Mean } \\
\text { Square }\end{array}$ & $\mathrm{F}$ & Sig. \\
\hline Regression & 123.716 & 1 & 123.716 & 85.003 & $.000^{\mathrm{b}}$ \\
\hline 1 Residual & 66.950 & 46 & 1.455 & & \\
\hline Total & 190.667 & 47 & & & \\
\hline
\end{tabular}

a. Dependent Variable: Produktivitas Kerja

b. Predictors: (Constant), Promosi Jabatan

Dari hasil Tabel 2 diketahui bahwa nilai $F$ hitung 85,003 dengan tingkat signifikan sebesar $0,000<0,05$, maka model regresi dapat dipakai untuk memprediksi

\section{Tabel 3}

variabel produktivitas kerja, atau dengan kata lain ada pengaruh variabel promosi jabatan (X) terhadap variabel produktivitas kerja (Y1).

ligus menunjukkan bahwa Hipotesis pertama (H1) diterima, yaitu promosi jabatan berpengaruh terhadap produktivitas kerja PNS Sekretariat Pemerintah Kota Makassar, dan pengaruhnya tergolong besar, yaitu berpengaruh sebesar $64,9 \%$.

Coefficients $^{\text {a }}$

\begin{tabular}{|r|r|r|r|r|r|}
\hline \multirow{2}{*}{ Model } & \multicolumn{2}{|c|}{$\begin{array}{c}\text { Unstandardized } \\
\text { Coefficients }\end{array}$} & $\begin{array}{c}\text { Standardized } \\
\text { Coefficients }\end{array}$ & \multirow{2}{*}{$\mathrm{T}$} & \multirow{2}{*}{ Sig. } \\
\cline { 2 - 4 } & \multicolumn{1}{|c|}{$\mathrm{B}$} & Std. Error & \multicolumn{1}{c|}{ Beta } & & \\
\hline \multirow{2}{*}{$\begin{array}{l}\text { (Constant) } \\
\text { Promosi } \\
\text { Jabatan }\end{array}$} & 37.943 & 1.732 & & 21.903 & .000 \\
\hline
\end{tabular}

a. Dependent Variable: Produktivitas Kerja

Dari hasil Tabel 3 diketahui nilai Constant (a) sebesar 37,943, sedangkan nilai promosi jabatan (b/ koefisien regresi) sebesar 0,227, sehingga persamaan regresi dapat ditulis:

$\mathrm{Y}=\mathrm{a}+\mathrm{bX}$

$Y=37,943+0,227$

Persamaan tersebut dapat diterjemahkan :
1. Konstanta sebesar 37,943 mengandung arti bahwa nilai konsisten variabel produktivitas kerja sebesar 37,943;

2. Koefisien regresi $X$ sebesar 0,227 , menyatakan bahwa setiap penambahan $1 \%$ nilai promosi jabatan, maka nilai produktivitas kerja bertambah 
sebesar 0,227. Koefisien regresi tersebut bernilai postif. Sehingga, dapat dikatakan bahwa arah pengaruh variabel $\mathrm{X}$ terhadap Y1 adalah positif.

Berdasarkan hasil penelitian diperoleh bahwa promosi jabatan (X) terhadap produktivitas kerja $\left(\mathrm{Y}_{1}\right)$ memiliki pengaruh yang besar. Berarti pegawai di Sekretariat Pemerintah Kota Makassar yang telah mendapatkan promosi jabatan, besar pengaruhnya terhadap produktivitas kerja mereka. Hasil penelitian ini searah dengan pernyataan yang dikemukakan oleh Abdurrahman (2009), bahwa promosi jabatan merupakan perkembangan yang positif dari seorang pekerja atau pegawai karena tugasnya dinilai baik oleh pejabat yang berwenang. Jika ada kesempatan untuk dipromosikan bagi setiap pegawai yang berdasarkan atas asas keadilan dan objektivitas akan mendorong karyawan bekerja lebih giat, semangat, berdisiplin dan berprestasi kerja yang semakin besar sehingga sasaran perusahaan yang optimal dapat dicapai.
Hasil penelitian ini juga menguatkan penelitian terdahulu dari Aisah (2018), pada karyawan Hotel Harris Vertu Yello Harmoni Jakarta, dimana hasil penelitiannya menunjukkan bahwa variabel promosi jabatan berpengaruh terhadap variabel produktivitas kerja karyawan. Begitu pula dengan penelitian Rismayanti dkk (2019), pada karyawan PT. Star Comgistic Indonesia Kabupaten Sukabumi, dimana hasil penelitiannya menunjukkan bahwa terdapat pengaruh positif dan signifikan antara promosi jabatan terhadap produktivitas kerja karyawan.

Tetapi, hasil penelitian ini tidak searah dengan penelitian yang dilakukan oleh Pramitasari (2018), pada karyawan PT. Pos Indonesia (PERSERO) Kabupaten Situbundo, dimana menunjukkan bahwa promosi jabatan tidak berpengaruh nyata terhadap produktivitas kerja karyawan.

B. Hasil Uji Regresi Linier Sederhana Pengaruh Promosi Jabatan (X) terhadap Semangat Kerja (Y2).

Tabel 4

Model Summary

\begin{tabular}{|l|r|r|r|r|}
\hline $\begin{array}{c}\text { Mode } \\
1\end{array}$ & \multicolumn{1}{c|}{$\mathrm{R}$} & R Square & Adjusted R Square & Std. Error of the Estimate \\
\hline 1 & $.787^{\mathrm{a}}$ & .619 & .610 & 1.29863 \\
\hline
\end{tabular}

a. Predictors: (Constant), Promosi Jabatan

Tabel 4 menjelaskan besarnya nilai korelasi/ hubungan (R) yaitu sebesar 0,787. Adapun nilai koefisien determinasi ( $\mathrm{R}$ Square) sebesar 0,619, yang mengandung arti bahwa pengaruh promosi jabatan $(\mathrm{X})$ terhadap semangat kerja (Y2) adalah 61,9\%. Hasil ini juga sekaligus menunjukkan bahwa Hipotesis kedua (H2) diterima, yaitu promosi jabatan berpengaruh 
terhadap semangat kerja PNS Sekretariat Pemerintah Kota Makassar, dan pengaruhnya tergolong besar, yaitu berpengaruh sebesar $61,9 \%$.

Tabel 5

ANOVA $^{\mathrm{a}}$

\begin{tabular}{|l|r|r|r|r|c|}
\hline Model & \multicolumn{1}{|c|}{$\begin{array}{c}\text { Sum of } \\
\text { Squares }\end{array}$} & \multicolumn{1}{c|}{ Df } & $\begin{array}{c}\text { Mean } \\
\text { Square }\end{array}$ & F & Sig. \\
\hline Regression & 125.903 & 1 & 125.903 & 74.656 & $.000^{\mathrm{b}}$ \\
1 Residual & 77.576 & 46 & 1.686 & & \\
\multicolumn{1}{l|}{ Total } & 203.479 & 47 & & & \\
\hline
\end{tabular}

a. Dependent Variable: Semangat Kerja

b. Predictors: (Constant), Promosi Jabatan

Dari hasil Tabel 5 diketahui bahwa nilai $\mathrm{F}$ hitung 74.656 dengan tingkat signifikan sebesar $0,000<0,05$, maka model regresi dapat dipakai untuk memprediksi variabel semangat kerja, atau dengan kata lain ada pengaruh variabel promosi jabatan (X) terhadap variabel semangat kerja (Y2).

Tabel 6

\section{Coefficients}

\begin{tabular}{|r|r|r|r|r|r|}
\hline \multirow{2}{*}{ Model } & \multicolumn{2}{|c|}{$\begin{array}{c}\text { Unstandardized } \\
\text { Coefficients }\end{array}$} & $\begin{array}{l}\text { Standardized } \\
\text { Coefficients }\end{array}$ & \multirow{2}{*}{$\mathrm{t}$} & \multirow{2}{*}{ Sig. } \\
\cline { 2 - 5 } & \multicolumn{1}{|c|}{$\mathrm{B}$} & Std. Error & \multicolumn{1}{c|}{ Beta } & & \\
\hline \multirow{2}{*}{$\begin{array}{l}\text { (Constant) } \\
\begin{array}{l}\text { Promosi } \\
\text { Jabatan }\end{array}\end{array}$} & -.301 & 1.865 & & -.161 & .872 \\
\hline
\end{tabular}

a. Dependent Variable: Semangat Kerja

Dari hasil Tabel 6 diketahui nilai Constant (a) sebesar -0,301, sedangkan nilai promosi jabatan (b/ koefisien regresi) sebesar 0,229 , sehingga persamaan regresi dapat ditulis:

$$
\begin{aligned}
& Y=a+b X \\
& Y=-0,301+0,229
\end{aligned}
$$

Persamaan tersebut dapat diterjemahkan:

1. Konstanta sebesar $-0,301$ mengandung arti bahwa nilai konsisten variabel semangat kerja sebesar -0,301;

2. Koefisien regresi $X$ sebesar 0,229 menyatakan bahwa setiap pengurangan $1 \%$ nilai promosi jabatan, maka nilai semangat kerja bertambah sebesar 0,229. Koefisien regresi tersebut bernilai negatif. Sehingga, dapat dikatakan bahwa arah pengaruh variabel $\mathrm{X}$ terhadap Y2 adalah negatif.

Berdasarkan hasil penelitian diperoleh bahwa promosi jabatan memiliki pengaruh yang besar terhadap semangat kerja PNS Sekretariat Pemerintah Kota Makassar. Hasil penelitian ini searah dengan pernyataan yang 
dikemukakan oleh Manullang (2001), bahwa ada beberapa sebab mengapa di dalam setiap organisasi perlu diambil tindakan promosi jabatan. Diantaranya ialah untuk meningkatkan semangat kerja pegawai. Bilamana promosi direalisasikan kepada mereka yang menghasilkan prestasi kerja yang tinggi, maka ada stimulus bagi para pegawai untuk mempertinggi semangat kerjanya. Semangat kerja yang tinggi sangat perlu bagi setiap organisasi, dan hal ini sebagian dapat diakibatkan oleh pemberian promosi yang objektif dan adil.

Hasil penelitian ini juga searah dengan penelitian sebelumnya dari Ramadhanni (2015), pada karyawan divisi redaksi pada PT. Tribun Pekanbaru, dimana menunjukkan bahwa promosi jabatan berpengaruh signifikan terhadap semangat kerja karyawan. Menguatkan pula penelitian yang dilakukan oleh Setiawan (2018), pada pegawai di Lingkungan Universitas Pembangunan Pancabudi Medan, dimana hasil penelitiannya juga menunjukkan adanya pengaruh promosi jabatan terhadap semangat kerja pegawai.

\section{PENUTUP}

\section{Simpulan}

Berdasarkan hasil analisis yang telah dilakukan, maka diperoleh kesimpulan, bahwa:

1. Promosi jabatan berpengaruh terhadap produktivitas kerja PNS Sekretariat Pemerintah Kota Makassar yang telah mendapatkan promosi jabatan pada tahun 2020;
2. Promosi jabatan berpengaruh terhadap semangat kerja PNS Sekretariat Pemerintah Kota Makassar yang telah mendapatkan promosi jabatan pada tahun 2020 .

\section{Saran}

Peneliti memberikan beberapa saran, agar:

1. Peneliti selanjutnya dapat menggunakan teori-teori dan konsep-konsep yang lebih mutakhir, yang terkait dengan promosi jabatan, produktivitas kerja, dan semangat kerja pegawai, berikut dengan indikatorindikatornya;

2. Peneliti selanjutnya dapat meneliti variabel independent maupun dependent yang berbeda dari penelitian ini, namun secara teori memiliki pengaruh satu sama lain;

3. Pihak-pihak yang berwenang dalam melakukan promosi jabatan, khususnya pada Sekretariat Pemerintah Kota Makassar, dapat senantiasa melakukan promosi jabatan secara adil, obyektif, dan sesuai dengan aturan yang berlaku, agar produktivitas dan semangat kerja para PNS Sekretariat Pemerintah Kota Makassar dapat semakin meningkat.

\section{DAFTAR PUSTAKA}

Aisah, L. I. (2018). Pengaruh Promosi Jabatan, Disiplin Kerja, dan Motivasi Kerja terhadap Produktivitas Kerja Karyawan di Hotel Harris Vertu Yello Harmoni. Jurnal Human Capital Development, 5(3), 47-63. 
Anoraga, P. (2004). Manajemen Bisnis (Cetakan Ke-3). Jakarta: PT. Rineka Cipta.

Ashari, E. T. (2009). Reformasi Pengelolaan SDM Aparatur Prasyarat Tata Kelola Birokrasi yang Baik. Jurnal Borneo Administrator, 6(2), 13-14.

Handoko, T. H. (1996). Manajemen Personalia Dan Sumber Daya Manusia. Yogyakarta: BPFE.

Hasibuan, M. (2016). Manajemen Sumber Daya Manusia. Jakarta: PT. Bumi Aksara.

Kusnendi. (2003). Ekonomi Sumber Daya Manusia dan Alam. Jakarta: Universitas Terbuka.

Manulang, M. (2001). Manajemen Personalia. Yogyakarta: Gajah Mada University Press.

Mathis, dkk. (2012). Manajemen Sumber Daya Manusia Edisi Pertama. Jakarta: Salemba Empat.

Nawawi, H. (2011). Manajemen Sumber Daya Manusia: untuk Bisnis yang Kompetitif. Yogyakarta: Gajah Mada University Press.

Pramitasari, T. D. (2018). Analisis Pengaruh Promosi Jabatan dan Disiplin Kerja pada Produktivitas Kerja Karyawan Pada PT. Pos Indonesia (PERSERO) di Kabupaten Situbundo. Jurnal Perilaku dan Strategi Bisnis, 6(1), 21-36.

Ramadhanni, R., \& Seno, A. (2015). Pengaruh Pelaksanaan Promosi Jabatan terhadap Semangat
Kerja Karyawan Divisi Redaksi pada PT. Tribun Pekanbaru. Jom FISIP, 2(2).

Rismayanti, dkk. (2019). Peran Promosi terhadap Peningkatan Produktivitas Kerja Karyawan (Study pada PT. Star Comgistic Indonesia Kabupaten Sukabumi). Jurnal Ekonomi dan Bisnis, 9(3), 303-312.

Rival, dkk. (2005). Manajemen Sumber Daya Manusia untuk Perusahaan. Jakarta: PT. Rajagrafindo Persada.

Setiawan, A. (2018). Pengaruh Promosi Jabatan dan Lingkungan Kerja terhadap Semangat Kerja Pegawai di Lingkungan Universitas Pembangunan Pancabudi Medan. Jurnal Akutansi Bisnis dan Publik, 8(2).

Siagian, S. P. (2009). Manajemen Sumber Daya Manusia (Edisi 3). Jakarta: PT. Bumi Aksara.

Siswanto, B. (2003). Manajemen Tenaga Kerja. Bandung: Sinar Baru.

Tohardi, A. (2002). Pemahaman Praktis Manajemen Sumber Daya Manusia. Bandung: Universitas Tanjung Pura, Mandar Maju.

Umar, H. (2000). Riset Sumber Daya Manusia dalam Organisasi. Jakarta: PT. Gramedia Pustaka Utama

Undang-Undang Nomor 5 Tahun 2014 Tentang Aparatur Sipil Negara. 